\title{
List of Bacterial Names with Standing in Nomenclature: a Folder Available on the Internet
}

\author{
J. P. EUZÉBY* \\ Laboratoire de Bactériologie, Ecole Nationale Vétérinaire, F-31076 Toulouse cedex 3, France
}

\begin{abstract}
The List of Bacterial Names with Standing in Nomenclature includes, alphabetically and chronologically, the official names of bacteria as published or validated in the International Journal of Systematic Bacteriology. It encompasses 5,569 taxa (as of 31 December 1996) and is available on the Internet (URL: ftp://ftp.cict.fr/pub/ bacterio/).
\end{abstract}

There is no official classification of bacteria, but there is an official nomenclature. The new starting date for bacteriological nomenclature is 1 January 1980, when the Approved Lists of Bacterial Names were published in the International Journal of Systematic Bacteriology (11). Despite every care, there were errors in the text of the Approved Lists, and these errors were corrected in the amended edition of the Approved Lists of Bacterial Names (12). Since 1980, on average, 200 new names or new combinations have been validly published every year, and in 1996 alone, more than 335 new names or nomenclatural changes were published. Also, it is sometimes difficult to swiftly find information, despite publication of the Index of the Bacterial and Yeast Nomenclatural Changes $(7,8)$.

The List of Bacterial Names with Standing in Nomenclature includes, alphabetically and chronologically, the official names of bacteria as published or validated in the International Journal of Systematic Bacteriology. This list encompasses 5,569 taxa (as of 31 December 1996). The citations of names are in the correct format according to the International Code of Nomenclature of Bacteria (5) (Rule 34a, note 1, is not followed because citations would be too long and because basonyms are given) and may differ from the citations used by the original authors. The appearance of a name on this list simply means that the name has been validly published according to the rules of nomenclature and is therefore valid.

The International Committee on Systematic Bacteriology has adopted a policy that "no names will be added to or removed from the Approved Lists of Bacterial Names" (11). "For this reason the Approved Lists of Bacterial Names will remain an independent publication" (10). However, to facilitate the search for information, the 2,336 names which appear on these lists are also included on the List of Bacterial Names with Standing in Nomenclature. (A total of 2,335 names were included in the body of the Approved Lists of Bacterial Names [11]. However, the family name Enterobacteriaceae was inserted in a footnote on page 236 , which indicated that the name was sub judice, referring to a proposal by Lapage [4]. In 1981, the Judicial Commission concluded that the family name Enterobacteriaceae Rahn 1937 is valid and should have been incorporated in the body of the Approved Lists of Bacterial Names [2]. A total of 2,337 names were included in the amended edition of The Approved Lists of Bacterial Names [12]; however, the name Eikenella corrodens appeared twice.)

Effective 28 March 1997, the List of Bacterial Names with Standing in Nomenclature will be available through URL/:ftp:

* Mailing address: Laboratoire de Bactériologie, Ecole Nationale Vétérinaire, 23 Chemin des Capelles, F-31076 Toulouse cedex 3, France. //ftp.cict.fr/pub/bacterio/. The folder (3.3 Mo) contains the following four files: "README": 26 Ko, "bacterAG.rtf": 1081 Ko, "bacterHR.rtf": $1140 \mathrm{Ko}$, and "bacterSZ.rtf": 757 Ko (the last file includes a "List of Candidatus" and a "List of Abbreviations for Some Culture Collections"). Publication on the Internet should allow an update every 3 months.

For every taxon, the nomenclatural type and a complete reference are given.

Example: Gluconobacter frateurii Mason and Claus 1989, sp. nov. - Type strain: strain ATCC 49207 = IFO 3264. - Reference: MASON (L.M.) and CLAUS (G.W.): Phenotypic characteristics correlated with deoxyribonucleic acid sequence similarities for three species of Gluconobacter: G. oxydans (Henneberg 1897) De Ley 1961, G. frateurii sp. nov., and G. asaii sp. nov. Int. J. Syst. Bacteriol., 1989, 39, 174-184.

If a name appears only on a validation list, the reference for effective publication is given in brackets.

Example: Dermabacter Jones and Collins 1989, gen. nov. - Type species: Dermabacter hominus Jones and Collins 1989. - References: VALIDATION LIST $\mathrm{N}^{\circ} 28$. Int. $J$. Syst. Bacteriol., 1989, 39, 93-94. [JONES (D.) and COLLINS (M.D.): Taxonomic studies on some human cutaneous coryneform bacteria: description of Dermabacter hominus gen. nov., sp. nov. FEMS Microbiol. Lett., 1988, 51, 51-56.]

An arrow $(\rightarrow)$ indicates:

(i) that a taxon is emended (emendavit)

Example: Acidaminococcus fermentans Rogosa 1969, species. - Type strain: strain ATCC 25085. - Reference Approved Lists of Bacterial Names.

$\rightarrow$ Acidaminococcus fermentans Rogosa 1969 (AL) emend. Cook et al. 1994. - Type strain: strain VR4 = ATCC 25085 = DSM 20731. - Reference: COOK (G.M.), RAINEY (F.A.), CHEN (G.), STACKEBRANDT (E.) and RUSSELL (J.B.): Emendation of the description of Acidaminococcus fermentans, a transaconitate- and citrate-oxidizing bacterium. Int. J. Syst. Bacteriol., 1994, 44, 576-578.

(ii) that one author (or several authors) proposes the transfer of a taxon to another genus (combinatio nova).

Example: Actinomadura flava Gauze et al. 1974, species. Type strain: strain ATCC 29533. — Reference: Approved 
Lists of Bacterial Names.

$\rightarrow$ Nocardiopsis flava (Gauze et al. 1974) Gauze and Sveshnikova 1985, comb. nov.

$\rightarrow$ Saccharothrix flava (Gauze et al. 1974) Grund and Kroppenstedt 1990, comb. nov.

(iii) that the rank of a taxon is changed.

Example: Branhamella Catlin 1970, genus. - Type species: Branhamella catarrhalis (Frosch and Kolle 1896) Catlin 1970 (AL). - Reference: Approved Lists of Bacterial Names.

$\rightarrow$ Moraxella (subgen. Branhamella) (Catlin 1970) Bøvre 1984, subgen. nov.

(iv) that a taxon is a junior synonym of an another taxon. Example: Rhodopseudomonas rutila Akiba et al. 1983, sp nov. - Type strain: strain R1 = ATCC 33872. - Reference: AKIBA (T.), USAMI (R.) and HORIKOSHI (K.): Rhodopseudomonas rutila, a new species of nonsulfur purple photosynthetic bacteria. Int. J. Syst. Bacteriol., 1983, 33, 551-556.

$\rightarrow$ Rhodopseudomonas palustris (Molisch 1907) van Niel 1944 (AL). - Rhodopseudomonas rutila Akiba et al. 1983 is a later subjective synonym of Rhodopseudomonas palus tris (Molisch 1907) van Niel 1944 (AL). - Reference: HIRAISHI (A.), SANTOS (T.S.), SUGIYAMA (J.) and KOMAGATA (K.): Rhodopseudomonas rutila is a later subjective synonym of Rhodopseudomonas palustris. Int. J. Syst. Bacteriol., 1992, 42, 186-188.

(v) that an exception to the rules has been awarded by the Judicial Commission of the International Committee on Systematic Bacteriology ("Requests for an opinion" denied or pending are not included).

Example: Citrobacter diversus (Burkey 1928) Werkman and Gillen 1932, species. - Type strain: strain ATCC 27156. - Reference: Approved Lists of Bacterial Names. $\rightarrow$ Citrobacter diversus nom. dub., nom. rejic. - Reference: JUDICIAL OPINION 67: Rejection of the name Citrobacter diversus Werkman and Gillen 1932. Int. J. Syst. Bacteriol., 1993, 43, 392. - Opinion requested by Frederiksen: FREDERIKSEN (W.): Correct names of the species Citrobacter koseri, Levinea malonatica, and Citrobacter diversus. Request for an opinion. Int. J. Syst. Bacteriol., 1990, 40, 107-108.

An equals sign $(=)$ means that two taxa are objective synonyms.

Example: Erwinia carnegieana Standring 1942, species. -

Type strain: strain NCPPB 439. - Reference: Approved Lists of Bacterial Names.

$=$ Pectobacterium carnegieana (Standring 1942) Brenner et al. 1973 (AL). - Rule 24b (1): Erwinia carnegieana Standring 1942 (AL) and Pectobacterium carnegieana (Standring 1942) Brenner et al. 1973 (AL) have the same type strain and therefore are objective synonyms.

Basonyms are given to clarify the previous names or histories of individual taxa.

Example: Saccharothrix flava (Gauze et al. 1974) Grund and Kroppenstedt 1990, comb. nov. - Basonyms: Actinomadura flava Gauze et al. 1974 (AL), Nocardiopsis flava (Gauze et al. 1974) Gauze and Sveshnikova 1985. - Type strain: strain ATCC $29533=$ DSM $43885=$ INA 2171. References: VALIDATION LIST $\mathrm{N}^{\circ} 34$. Int. J. Syst. Bac teriol., 1990, 40, 320-321. [GRUND (E.) and KROPPENSTEDT (R.M.): Transfer of five Nocardiopsis species to the genus Saccharothrix Labeda et al. 1984. Syst. Appl. Microbiol., 1989, 12, 267-274.]

Annotations are made:

(i) to clarify the rules or rationale for some nomenclatural changes.

Example: Streptomyces luteosporeus Witt and Stackebrandt 1991, nom. nov. - Synonym: Streptoverticillium album Locci et al. 1969 (AL). - Type strain: strain NRRL 2401 = ATCC 33049. - References: VALIDATION LIST $\mathrm{N}^{\circ}$ 38. Int. J. Syst. Bacteriol., 1991, 41, 456-457. [WITT (D.) and STACKEBRANDT (E.): Unification of the genera Streptoverticillium and Streptomyces, and emendation of Streptomyces Waksman and Henrici 1943, 339 ${ }^{\mathrm{AL}}$. Syst. Appl. Microbiol., 1990, 13, 361-371.]

Note: For the transfer of Streptoverticillium album in the genus Streptomyces, it is necessary to substitute a new specific epithet to produce Streptomyces luteosporeus because there is a senior homonym, Streptomyces albus (Rossi Doria 1891) Waksman and Henrici 1943, included on the Approved Lists of Bacterial Names (rules 34a and 41a).

(ii) to specify that a taxon is a senior synonym of an another taxon.

Example: Rhodopseudomonas palustris (Molisch 1907) van Niel 1944, species. - Type strain: strain ATCC 17001. Reference: Approved Lists of Bacterial Names.

Note: Rhodopseudomonas palustris (Molisch 1907) van Niel 1944 (AL) is a senior synonym of Rhodopseudomonas rutila Akiba et al. 1983. - Reference: HIRAISHI (A.), SANTOS (T.S.), SUGIYAMA (J.) and KOMAGATA (K.): Rhodopseudomonas rutila is a later subjective synonym of Rhodopseudomonas palustris. Int. J. Syst. Bacteriol., 1992, 42, 186-188.

(iii) to mention that spelling has been corrected (corrigendum).

Example: Mycobacterium chelonae corrig. Bergey et al. 1923, species. - Type strain: strain NCTC 946. - Reference: Approved Lists of Bacterial Names.

Note: The original spelling, Mycobacterium chelonei (sic), has been corrected by Hill et al. 1984. - Reference: HILL (L.R.), SKERMAN (V.B.D.) and SNEATH (P.H.A.): Corrigenda to the Approved Lists of Bacterial Names edited for the International Committee on Systematic Bacteriology. Int. J. Syst. Bacteriol., 1984, 34, 508-511.

(iv) to propose a corrected spelling.

Example: Bacteroides tectum Love et al. 1986, sp. nov. Type strain: strain $160=$ NCTC 11853.--Reference: LOVE (D.N.), JOHNSON (J.L.), JONES (R.F.) BAILEY (M.) and CALVERLEY (A.): Bacteroides tectum sp. nov. and characteristics of other nonpigmented Bacteroides isolates from soft-tissue infections from cats and dogs. Int. J. Syst. Bacteriol., 1986, 36, 123-128.

Note: According to rule 61, the original spelling should be changed to Bacteroides tectus.

The infrasubspecific subdivisions (biovars, chemovars, pathovars, phagovars, serovars, etc.) are not covered by the rules of the Bacteriological Code (5) and are not included. When the name of an infrasubspecific subdivision is cited, to 
avoid confusion, it is printed in roman type (not italics), starting with a capital letter (6).

Example: Xanthomonas vasicola Vauterin et al. 1995, sp. nov. - Type strain: strain $X$. vasicola pv. Holcicola LMG $736=$ NCPPB $2417=$ ICMP $3103=$ CFBP 2543. Reference: VAUTERIN (L.), HOSTE (B.), KERSTERS (K.) and SWINGS (J.): Reclassification of Xanthomonas. Int. J. Syst. Bacteriol., 1995, 45, 472-489.

Names in quotation marks are not on the Approved Lists of Bacterial Names, have not been validly published since 1 January 1980, and therefore do not have nomenclatural standing.

Example: Acinetobacter haemolyticus (ex Stenzel and Mannheim 1963) Bouvet and Grimont 1986, sp. nov., nom. rev., comb. nov. - Basonym: "Achromobacter haemolyticus" Stenzel and Mannheim 1963. - Type strain: strain Mannheim 2446/60 = CIP 64.3 = B40 = ATCC 17906. - Reference: BOUVET (P.J.M.) and GRIMONT (P.A.D.): Taxonomy of the genus Acinetobacter with the recognition of Acinetobacter baumannii sp. nov., Acinetobacter haemolyticus sp. nov., Acinetobacter johnsonii sp. nov., and Acinetobacter junii sp. nov. and emended descriptions of Acinetobacter calcoaceticus and Acinetobacter lwoffi. Int. J. Syst. Bacteriol., 1986, 36, 228-240.

The category Candidatus is a new nomenclatural concept proposed by Murray and Schleifer (9) to record the properties of putative taxa of procaryotes which would have indefinite rank. This category should be used for describing procaryotic entities for which more than a mere sequence is available but for which characteristics required for description according to the Bacteriological Code (5) are lacking. The category Candidatus, which is not a rank but a status, is not formally recognized in the Bacteriological Code (5). However, the Judicial Commission recommended to the International Committee on Systematic Bacteriology that a Candidatus list should be established in the International Journal of Systematic Bacteriology (3). Therefore, a list of Candidatus taxa appears in an annex.

Example: "Candidatus comitans" Jacobi et al. 1996. Nucleic acid sequence: EMBL X91814. - Reference: JACOBI (C.A.), REICHENBACH (H.), TINDALL (B.J.) and STACKEBRANDT (E.): "Candidatus comitans," a bacterium living in coculture with Chondromyces crocatus (Myxobacteria). Int. J. Syst. Bacteriol., 1996, 46, 119-122.

Abbreviations and addresses of some collections from which type strains are available are included at the end of the list.

The omission of some diacritical signs was dictated by the limitations of the computer.

As says Le Gros, cited by Buchanan (1), "Dans ce genre de travail il est presque impossible de ne pas faire d'erreurs..." Also, I would appreciate factual information concerning any errors or corrections for this list.

\section{REFERENCES}

1. Buchanan, R. E., J. G. Holt, and E. F. Lessel, Jr. 1966. Index bergeyana, p. VII-XII. The Williams \& Wilkins Company, Baltimore, Md.

2. Judicial Commission of the International Committee on Systematic Bacteriology. 1981. Present standing of the family name Enterobacteriaceae Rahn 1937. Int. J. Syst. Bacteriol. 31:104.

3. Judicial Commission of the International Committee on Systematic Bacteriology. 1995. Minutes of the meetings, 2 and 6 July 1994, Prague, Czech Republic. Int. J. Syst. Bacteriol. 45:195-196.

4. Lapage, S. P. 1979. Proposal of Enterobacteraceae nom. nov. as a substitute for the illegitimate but conserved name Enterobacteraceae Rahn 1937. Request for an opinion. Int. J. Syst. Bacteriol. 29:265-266.

5. Lapage, S. P., P. H. A. Sneath, E. F. Lessel, V. B. D. Skerman, H. P. R. Seeliger, and W. A. Clark (ed.). 1992. Bacteriological Code (1990 Revision). American Society for Microbiology, Washington, D. C.

6. Le Minor, L., and M. Y. Popoff. 1987. Designation of Salmonella enterica sp. nov., nom. rev., as the type and only species of the genus Salmonella. Request for an opinion. Int. J. Syst. Bacteriol. 37:465-468.

7. Moore, W. E. C., and L. V. H. Moore. 1989. Index of the bacterial and yeast nomenclatural changes published in the International Journal of Systematic Bacteriology since the 1980 Approved Lists of Bacterial Names (1 January 1980 to 1 January 1989). American Society for Microbiology, Washington, D. C.

8. Moore, W. E. C., and L. V. H. Moore. 1992. Index of the bacterial and yeast nomenclatural changes published in the International Journal of Systematic Bacteriology since the 1980 Approved Lists of Bacterial Names (1 January 1980 to 1 January 1992). American Society for Microbiology, Washington, D. C.

9. Murray, R. G. E., and K. H. Schleifer. 1994. Taxonomic notes: a proposal for recording the properties of putative taxa of procaryotes. Int. J. Syst. Bacteriol. 44:174-176.

10. Skerman, V. B. D. 1989. Preface, p. V-VI. In V. B. D. Skerman, V. McGowan, and P. H. A. Sneath (ed.), Approved lists of bacterial names, amended edition. American Society for Microbiology, Washington, D. C.

11. Skerman, V. B. D., V. McGowan, and P. H. A. Sneath (ed.). 1980. Approved lists of bacterial names. Int. J. Syst. Bacteriol. 30:225-420.

12. Skerman, V. B. D., V. McGowan, and P. H. A. Sneath. 1989. Approved lists of bacterial names, amended edition. American Society for Microbiology, Washington, D. C. 